\title{
MENINGKATKAN MINAT DAN HASIL BELAJAR SISWA MENGGUNAKAN MODELNHT NUMBER HEADS TOGETHER (NHT) PADA MATA PELAJARAN MATEMATIKA
}

\author{
Andri', Ratih Sarni Purwanti ${ }^{2}$ \\ 1,2 STKIP Persada Khatulistiwa Sintang \\ e-mail: ${ }^{1}$ andry_tkr@yahoo.com, ${ }^{2}$ ratihsarnipurwanti13@gmail.com
}

\begin{abstract}
The purpose of this study was to determine the increase in interest and student learning outcomes using the NHT (Number Heads Together) model on mathematics subjects in fifth grade students of SDN 01 Ketungau Hilir Academic Year 2018/2019. Data collection techniques are carried out through observation, measurement, indirect communication techniques and documentation. Data collection tools are observation sheets, test questions, and questionnaire sheets. The results of this study indicate that in the first cycle students' interest in learning with an average of 34.17 and classical completeness of $55.17 \%$ and student learning outcomes in the first cycle averaged 39.46 with classical completeness $32.14 \%$. In the second cycle learning interest reached 45.96 with classical completeness of $77.38 \%$. And student learning outcomes in the second cycle with an average of 80.89 and classical completeness of $92.85 \%$. Based on the results of data analysis it can be concluded that the use of the NHT (Number Heads Together) model can increase students' interest and learning outcomes on mathematics subjects in fifth grade students of SDN 01 Ketungau Hilir Academic Year 2018/2019
\end{abstract}

Keyword: Interest in Learning, Learning Outcomes, and NHT Models

\begin{abstract}
Abstrak. Tujuan penelitian ini adalah untuk mengetahui peningkatan minat dan hasil belajar siswa menggunakan model NHT (Number Heads Together) pada mata pelajaran matematika siswa kelas V SDN 01 Ketungau Hilir Tahun Pelajaran 2018/2019. Teknik pengumpulan data dilakukan melalui observasi, pengukuran, teknik komunikasi tidak langsung dan dokumentasi. Alat pengumpulan data adalah lembar observasi, soal tes, dan lembar angket. Hasil penelitian ini menunjukkan bahwa pada siklus I minat belajar siswa dengan rata-rata 34,17 dan ketuntasan klasikal sebesar 55,17\% serta hasil belajar siswa siklus I rata-rata 39,46 dengan ketuntasan klasikal 32,14\%. Pada siklus II minat belajar mencapai 45,96 dengan ketuntasan klasikal sebesar 77,38\%. Dan hasil belajar siswa pada siklus II dengan rata-rata 80,89 dan ketuntasan klasikal sebesar 92,85\%. Berdasarkan hasil analisis data dapat disimpulkan bahwa penggunaan model NHT (Number Heads Together) dapat meningkatkan minat dan hasil belajar siswa pada mata pelajaran matematika siswa kelas V SDN 01 Ketungau Hilir Tahun Pelajaran 2018/2019.
\end{abstract}

Kata Kunci: Minat Belajar, Hasil Belajar, dan Model NHT 


\section{PENDAHULUAN}

Pendidikan adalah usaha sadar dan terencana untuk mewujudkan suasana belajar dan proses pembelajaran, agar peserta didik dapat mengembangkan potensi dirinya secara aktif. Menurut Longeveled (Hafid, dkk 2013 : 28), "Pendidikan adalah suatu usaha, pengaruh, perlindungan dan bantuan yang diberikan kepada anak agar tertuju kepada kedewasaannya, atau membantu anak agar cukup cakap melaksanakan tugas hidupnya sendiri”. Hal tersebut sejalan dengan pendapat Dalle (Hafid,dkk 2013:29), "Pendidikan adalah usaha sadar yang dilakukan oleh keluarga, masyarakat, dan pemerintah melalui kegiatan bimbingan, pembelajaran, dan latihan, yang berlangsung disekolah dan diluar sekolah sepanjang hayat untuk mempersiapkan peserta didik agar dapat mempermainkan peranan dalam berbagai lingkungan hidup secara tetap untuk masa yang akan datang”.

Selama ini pandangan bahwa matematika merupakan pelajaran yang sangat menakutkan masih belum berubah. Hal ini sejalan dengan pendapat Marti (Sundayana, 2015:2) mengatakan bahwa, matematika dianggap memiliki tingkat kesulitan yang tinggi, namun setiap orang harus mempelajarinya karena merupakan sarana untuk memecahkan masalah sehari-hari. Rendahnya hasil belajar siswa dapat mempengaruhi kualitas belajar peserta didik. Menurut Hilgard (Slameto, 2013: 57) Minat adalah kecenderungan yang tetap untuk memperhatikan dan mengenang beberapa kegiatan. Kegiatan yang diminati seseorang, diperhatikan terus menerus yang disertai dengan rasa senang.Menurut Purwanto(2016 : 44), Hasil belajar seringkali digunakan untuk mengetahui seberapa jauh seseorang menguasai bahan yang sudah diajarkan. Kingsley (Sudjana, 2014:22) membagi tiga macam hasil belajar, yakni (a) keterampilan dan kebiasaan, (b) pengetahuan dan pengertian, (c) sikap dan cita-cita. Masingmasing jenis hasil belajar dapat diisi dengan bahan yang telah ditetapkan dalam kurikulum.

Berdasarkan hasil observasi awal pada tanggal 4 April sampai 5 April 2018 pada siswa kelas V SDN 01 Ketungau Hilir, peneliti menyebarkan angket minat yaitu terdapat 20 pertanyaan yang diajukan kepada 26 siswa untuk mengetahui minat siswa dalam pembelajaran matematika. Terdapat 19 orang siswa tidak menyukai pelajaran matematika dan mengungkapkan matematika merupakan pelajaran yang sangat sulit, serta 7 orang siswa senang dengan pelajaran matematika, jadi dari hasil angket yang telah dibagikan terdapat $73 \%$ siswa yang tidak berminat pada pelajaran matematika, 27\% siswa menyukai pelajaran matematika. Dengan rendahnya minat siswa terhadap pelajaran matematika berdampak pada hasil belajar siswa, berdasarkan hasil ulangan harian metematika dari 26 siswa hanya 8 orang siswa yang mampu mencapai ketuntasan , dan 18 siswa lainnya mendapatkan nilai dibawah rata-rata, dan $70 \%$ siswa tidak tuntas dan $30 \%$ siswa 
yang tuntas. Berdasarkan hasil temuan sewaktu obsevasi awal mengartikan bahwa minat dan hasil belajar pada siswa kelas $\mathrm{V}$ SDN 01 Ketungau Hilir masih rendah.

Rendahnya hasil belajar siswa dapat mempengaruhi kualitas belajar peserta didik. Menurut Hilgard (Slameto, 2013: 57) Minat adalah kecenderungan yang tetap untuk memperhatikan dan mengenang beberapa kegiatan. Kegiatan yang diminati seseorang, diperhatikan terus menerus yang disertai dengan rasa senang.Menurut Purwanto ( 2016 : 44), Hasil belajar seringkali digunakan untuk mengetahui seberapa jauh seseorang menguasai bahan yang sudah diajarkan. Horward Kingsley (Sudjana, 2014:22) membagi tiga macam hasil belajar, yakni (a) keterampilan dan kebiasaan, (b) pengetahuan dan pengertian, (c) sikap dan cita-cita. Masing-masing jenis hasil belajar dapat diisi dengan bahan yang telah ditetapkan dalam kurikulum. Sedangkan Gagne (Slameto, 2013:22) membagi lima kategori hasil belajar, yakni (a) informasi verbal, (b) keterampilan intelektual, (c) strategi kognitif, (d) sikap, dan (e) keterampilan motoris.

Permasalahan lain yang ditemukan yaitu guru ketika didalam proses pembelajaran matematika masih belum menggunakan metode pembelajaran yang inovatif, metode, model atau strategi yang digunakan belum bervariasi serta dapat memotivasi siswa untuk mengikuti pembelajaran matematika, hasil wawancara dengan siswa dan siswa ditemukan bahwa siswa merasa kesulitan belajar dengan matematika sehingga berdampak pada tidak menyukai pembelajaran matematika, guru juga mengatakan siswa sulit menyelesaikan masalah metematika dan menyampaikan bahwa sulit memilih model atau metode yang tepat untuk pembelajaran matematika. Berdasarkan permasalahan yang ditemukan peneliti ingin memberikan salah satu alternatif untuk meningkatkan minat dan hasil belajar matematika dengan model number heads together (NHT).

Menurut Slavin (Huda,2015:203), metode yang dikembangkan oleh Russ Frank ini cocok untuk memastikan akuntabilitas individu dalam diskusi kelompok. Tujuan dari NHT (Number Heads Together) adalah memberi kesempatan kepada siswa untuk saling berbagi gagasan dan mempertimbangkan jawaban yang paling tepat. Selain untuk meningkatkan kerja sama siswa, NHT (Number Heads Together) juga bisa diterapkan untuk semua mata pelajaran dan tingkatan kelas. Shoimin (2014:107) mengartikan NHT (Number Heads Together) merupakan salah satu dari strategi pembelajaran kooperatif, NHT juga merupakan model pembelajaran berkelompok yang setiap anggota kelompoknya bertanggung jawab atas tugas kelompoknya, sehingga tidak ada pemisahan antar siswa yang satu dan siswa yang lain dalam satu kelompok untuk saling memberi dan menerima anatar satu dengan yang lainnya. Menurut Shoimin

(2014:108-109) mengemukakan ada lima kelebihan model NHT(Number Heads Together) yaitu: 1)Setiap murid menjadi siap, 2) Dapat 
melakukan diskusi dengan sungguh-sungguh, 3) Murid yang pandai dapat mengajari murid yang kurang 4) Terjadi interaksi secara intens antarsiswa dalam menjawab soal, dan 5) Tidak ada murid yang mendominasi dalam kelompok karena ada nomor yang membatasi.

Dapat diketahui keberhasilan proses belajar proses belajar siswa dipengaruhi oleh dua faktor yaitu faktor internal dan faktor eksternal. Faktor internal meliputi kecerdasan, bakat, minat, perhatian orang tua, motivasi, kesehatan jasmani, dan cara belajar siswa itu sendiri. Faktor eksternal meliputi keluarga, lingkungan, guru, masyarakat, sekolah, serta media pembelajaran.Berdasarkan pengamatan yang dilakukan peneliti dilapangan bahwa rendahnya minat belajar disebabkan siswa kurang menyukai pelajaran matematika ini dibuktikan berdasarkan lembar angket yang dibagikan.

Berdasarkan permasalahan dan keunggulan model pembelajaran yang telah dipaparkan diatas, maka peneliti ingin menerap model NHT (Number Heads Together) untuk meningkatkan minat dan hasil belajar matematika. Dengan tujuan Untuk mendeskripsikan penerapan model NHT (numbered heads together) pada pelajaran matematika, untuk meningkatkan minat dan hasil belajar siswa menggunakan model NHT (number heads together) pada pelajaran Matematika siswa kelas V SDN 01 Ketungau Hilir Tahun Ajaran 2018/2019.

\section{METODE}

Pendekatan pada penelitian ini adalah penelitian kualitatif deskriptif, sedangkan bentuk penelitian yang digunakan yaitu penelitian tindakan kelas dengan tujuan meningkakan minat dan hasil belajar siswa. Arikunto (2014: 3) menyatakan bahwa, penelitian tindakan kelas merupakan suatu pencermatan terhadap kegiatan belajar berupa sebuah tindakan, yang sengaja dimunculkan dan terjadi dalam sebuah kelas secara bersama.

Tempat penelitian ini adalah di SDN 01 Ketungau Hilir yang berada di jalan ketungau indah, kecamatan Ketungau Hilir, Kabupaten Sintang Provinsi Kalimantan Barat, dengan subyek penelitian siswa kelas V SDN 01 Ketungau Hilir tahun ajaran 2018/2019, dengan jumlah siswanya 26 orang, 11 orang siswa laki-laki dan 17 orang siswa perempuan.

Pengumpulan data dilakukan dengan empat teknik yaitu observasi, pengukuran, komunikasi tidak langsung, dan dokumentasi. Alat pengumpulan data pada penelitian ini yaiu lembar observasi, Soal Tes, dan Angket.

\section{HASIL DAN PEMBAHASAN}

\section{Hasil}

\section{Pelaksanaan Tindakkan}

Tahap awal dalam melaksanakan PTK yaitu perencanaan. Perencanaan pada pembelajaran dengan menggunakan model NHT (number heads together) guru menyiapkan RPP, Lembar Observasi yaitu lembar observasi aktivitas guru dan aktivitas 
siswa, Soal tes untuk mengetahui peningkatan penggunaan model NHT (Number Heads Together), lembar angket minat untuk mengetahui minat belajar siswa. Selain itu peneliti juga menyiapkan media pembelajaran yaitu kartu bernomor.

Kegiatan pembelajaran dengan model NHT setelah melakukan pendahuluan yaitu salam, apersepsi dan menyampaikan tujuan pembelajaran guru menjelaskan materi yang sesuai dengan indikator pembelajaran yaitu materi bangun ruang kubus dan balok. Kemudian guru membagi kelompok dan memberi nomor disetiap anggota kelompoknya masing-masing, yang pertama dipilih ketua kelompok 1 sampai 6 siswa dengan memilih siswa yang memiliki kemampuanya lebih dari rata-rata, setelah itu menggunakan hitungan sampai 1 sampai 6 . Misalnya nomor 3 masuk ke kelompok 3 dan seterusnya sampai semua siswa mendapatkan kelompoknya masing-masing. Guru mengajukan pertanyaan atau memberi tugas pada masing-masing kelompok untuk mengerjakannya. Setiap kelompok mulai berdiskusi untuk menemukan jawaban yang dianggap paling tepat. Selanjutnya guru memanggil salah satu nomor secara acak. Kemudian siswa dengan nomor yang dipanggil mempersentasikan jawaban dari hasil diskusi kelompok mereka, kemudian guru memberikan penilaian kepada setiap kelompok yang menjawabnya. Alat penilaian menggunakan skor misalnya kelompok 1 mengerjakan soal dengan benar mendapat nilai skor 20 dan seterusnya sampai soal yang diberikan guru habis.

\section{Aktivitas Siswa dan Guru}

Aktivitas siswa dan aktivitas guru diamati dengan lembar observasi yang diisi oleh observer pada saat proses pemebelajaran dengan model NHT berlangsung. Pada siklus I aktivitas siswa 65\% dengan kategori cukup dan pada siklus II hasil observasi aktivitas siswa dengan persentase $90 \%$ kategori sangat baik, hasil ini mengartikan ada peningkatan aktivitas belajar siswa dari siklus I ke siklus II dan kriteria keaktifan siswa juga sudah terpenuhi pada siklus II.

Aktivitas Guru pada siklus I sebesar 74,4 \% masuk kategori baik dan pada siklus II sebesar 94,44\% dengan kategori sangat baik, hasil observasi aktivitas guru juga mengalami peningkatan dari siklus I ke siklus II, hasil ini juga mengartikan bahwa aktivitas guru sudah berjalan dengan baik dan sudah memenuhi kriteria ketuntasan.

\section{Minat Belajar}

Hasil lembar angket siklus I dapat dilihat pada tabel 1 berikut:

\section{Tabel 1 Rekapitulasi Hasil Minat Belajar Siswa Siklus I}

\begin{tabular}{llc}
\hline No. & \multicolumn{1}{c}{ Hasil Tes } & Siklus I \\
\hline 1 & Sangat Setuju & 5 \\
2 & Setuju & 4 \\
3 & Tidak Setuju & 8 \\
4 & Sangat Tidak Setuju & 11 \\
5 & Rata-rata & 34,71 \\
6 & Persentase Klasikal & $55,17 \%$ \\
& Kriteria & Kurang \\
\hline
\end{tabular}


Berdasarkan data pada tabel diatas, maka dapat diketahui bahwa hasil lembar angket minat belajar siklus I yang disebarkan oleh peneliti pada 28 orang siswa kelas $\mathrm{V}$ memperoleh jumlah sebanyak 972 dengan persentase 55,17\% (kategori kurang). Berdasarkan hasil yang diperoleh tersebut, maka peneliti dapat menyimpulkan bahwa minat belajar siswa masih kurang. Untuk itu peneliti akan melakukan perbaikan pada siklus berikutnya yaitu siklus II

Hasil angket minat belajar siswa siklus II dapat dilihat pada tabel 2 berikut ini:

Tabel 2. Rekapitulasi Hasil Minat Belajar Siswa Siklus II

\begin{tabular}{clc}
\hline No. & \multicolumn{1}{c}{ Hasil Tes } & Siklus II \\
\hline 1 & Sangat Setuju & 10 \\
2 & Setuju & 11 \\
3 & Tidak Setuju & 5 \\
4 & Sangat Tidak Setuju & 2 \\
5 & Rata-rata & 45,96 \\
6 & Persentase Klasikal & $77,38 \%$ \\
& Kriteria & BAIK \\
\hline
\end{tabular}

Berdasarkan data pada tabel diatas, maka dapat diketahui bahwa lembar angket minat siswa pada siklus II yang disebarkan oleh peneliti, dan mendapatkan hasil 77,38\% dengan kriteria baik. Berdasarkan kriteria minat yang sudah disebutkan diawal penelitian bahwa minat belajar dikatakan meningkat apabila sudah mencapai kriteria baik dan mencapai skor $75 \%-85 \%$ dari hasil persentase yang diperoleh peneliti pada siklus II ini menyatakan bahwa minat belajar siswa sudah baik dan dapat dikatakan bahwa penelitian berhenti pada siklus II

\section{Hasil Belajar}

Hasil belajar siswa pada siklus I dapat dilihat pada tabel 3 berikut ini:

Tabel 3. Hasil Belajar Siklus I

\begin{tabular}{clc}
\hline No. & \multicolumn{1}{c}{ Hasil Tes } & Siklus I \\
\hline 1 & Nilai Tertinggi & 75 \\
2 & Nilai Terendah & 15 \\
3 & Rata-rata & 39,46 \\
4 & Nilai Klasikal & $32,14 \%$ \\
5 & Kriteria & Kurang \\
\hline
\end{tabular}

Berdasarkan data pada tabel 4.5 diatas dapat diketahui bahwa dari 5 soal yang diberikan terdapat 9 orang siswa yang mendapatkan nilai tuntas sedangkan 19 orang siswa tidak tuntas, dan dengan jumlah nilai siswa keseluruhan adalah 1.105. Berdasarkan jumlah nilai siswa tersebut ketuntasan siswa secara klasikal yaitu $32,14 \%$ (kategori kurang) dan penelitian dilanjutkan pada siklus II.

Hasil belajar siswa siklus II dapat dilihat pada tabel 4 berikut ini:

Tabel 4. Hasil Belajar Siklus II

\begin{tabular}{ccc}
\hline No. & Hasil Tes & Siklus II \\
\hline 1 & Nilai Tertinggi & 100
\end{tabular}


2 Nilai Terendah

3 Rata-rata

$4 \quad$ Nilai Klasikal

$5 \quad$ Kriteria
60

80,89

$92,85 \%$

Sangat Baik
Berdasarkan data pada tabel diatas, maka dapat diketahui bahwa dari soal yang telah dikerjakan oleh siswa kelas $\mathrm{V}$ pada siklus II ini sebanyak 24 siswa dapat mengerjakan soal dengan baik dan mendapatkan nilai tuntas atau diatas nilai KKM, dan 4 orang siswa yang masih belum mendapatkan nilai tuntas. Dari jumlah siswa yang mendapatkan nilai tuntas tersebut maka selanjutnya dapat diketahui jumlah nilai dari seluruh siswa adalah 2.265 dengan rata-rata nilai $80,89 \%$ dan ketuntasan secara klasikal adalah $92,85 \%$ dengan predikat sangat baik.

Sesuai dengan ketuntasan klasikal yang sudah ditetapkan sebelumnya, dikatakan bahwa hasil belajar tuntas apabila dalam satu kelas ketuntasan siswa mencapai $85 \%$. Dari hasil yang diperoleh tersebut peneliti menyimpulkan bahwa hasil belajar siklus II sudah tuntas secara klasikal maupun secara individu. Untuk itu, penelitian berhenti pada siklus II

\section{Pembahasan}

1. Penggunaan Model NHT (Number Heads Together) pada mata pelajaran matematika.

Penggunaan model NHT (Number Heads Together) pada mata pelajaran matematika dapat terukur melalui kegiatan observasi aktivitas mengajar yang dilakukan oleh guru dan aktivitas belajar siswa dikelas. Berdasarkan observasi aktivitas mengajar guru yang dilakukan oleh peneliti pada siklus I diketahui bahwa aktivitas mengajar guru memperoleh rata-rata 74,4 dengan kategori cukup baik. Walaupun sudah cukup baik ternyata masih terdapat kekurangan yang tidak dilakukan oleh peneliti, yaitu guru kurang memberikan motivasi pada siswa selama pembelajaran berlangsung. Padahal menurut Slameto (2013:30) mengatakan bahwa "guru membimbing, menunjukkan jalan dengan memperhitungkan kepribadian siswa, kesempatan untuk berbuat dan aktif berpikir lebih banyak diberikan kepada siswa, dari pada teori yang lain".

Berdasarkan kekurangan tersebut, maka diadakan upaya perbaikan pada siklus berikutnya. Upaya peningkatan kualitas pembelajaran dilakukan dengan cara guru meningkatkan pemberian motivasi kepada siswa. Setelah dilakukan perbaikan pada siklus II, kualitas mengajar guru sudah jauh lebih baik dari sebelumnya. Hal ini terbukti dengan hasil yang diperoleh pada siklus I dan II dengan rata-rata 74,4 meningkat menjadi 94,44 atau dengan kategori baik menjadi sangat baik.

Pada kegiatan siklus II ini aktivitas mengajar guru dalam semua aspek sudah dilakukan dengan baik. Untuk itu dapat dikatakan bahwa terdapat peningkatan dari siklus I kesiklus II. Peningkatan kualitas mengajar guru ini menyebabkan suasana 
pembelajaran menjadi lebih kondusif, siswa lebih aktif dan antusias mengikuti pembelajaran, serta hasil belajar siswa semakin bermakna melalui pengalaman lansung yang diperoleh dari kegiatan pembelajaran yang dikemas oleh guru. Dengan demikian, maka aktivitas guru pada siklus II berhasil.

Setelah melihat hasil dari kegiatan aktivitas guru, maka selanjutnya penggunaan model NHT (Number Heads Together) juga dapat dilihat berdasarkan kegiatan aktivitas belajar siswa dilakukan sebanyak 2 kali pada setiap siklus yaitu pada pertemuan pertama dan pertemuan kedua. Pada siklus I aktivitas belajar siswa secara keseluruhan masih kurang. Hal ini ditunjukkan dengan peroleh persentase aktivitas belajar siswa yang sudah mencapai 32,14\% dengan kategori kurang. Hal ini disebabkan siswa kurang antusias dalam menjawab pertanyaan guru yang terkait dengan materi pembelajaran. Selain itu, siswa juga kurang berpartisipasi dalam kelompok yang telah dibagikan oleh guru, hanya beberapa siswa saja yang aktif dalam kelompok tersebut. Hal ini tentunya terjadi karena siswa belum terbiasa belajar menggunakan model NHT (Number Heads Together) yang guru terapkan.

Pada siklus II, aktivitas belajar siswa meningkat dari siklus I sebelumnya. Siswa sudah dapat melaksanakan tugasnya dengan maksimal, baik dalam kelompok maupun idividu. Siswa juga sudah terbiasa belajar menggunakan model NHT (Number Heads Together) dalam pembelajaran matematika yang guru sampaikan. Dalam diskusi kelompok pun tidak hanya siswa yang aktif saja yang mengerjakan namun semua siswa yang ada didalam kelompok tersebut ikut terlibat dalam diskusi kelompok. Hal ini, sesuai dengan data penelitian yang telah diperoleh peneliti, yaitu pada siklus II meningkat dari awalnya hanya $65 \%$ meningkat menjadi 90\% dengan kategori dari mulainya cukup menjadi sangat baik. Dengan demikian, maka aktivitas belajar siswa pada siklus II dengan menerapkan model NHT (Number Heads Together) masuk kriteria baik.

Dari hasil pemaparan yang telah dijabarkan diatas, maka dengan menggunakan model NHT (Number Heads Together) dapat meningkatkan aktivitas siswa dan guru hal ini sesuai dengan pendapat Joyce dan Weil (Fathurrohman, 2015:30) mendefinisikan model pembelajaran sebagai suatu perencanaan atau suatu pola yang digunakan sebagai pedoman dalam melaksanakan pembelajaran dikelas atau pembelajaran dalam tutorial dan untuk menentukan perangkat-perangkat pembelajaran. dan didukung oleh Rusman (2014:204) ketergantungan yang positif adalah suatu bentuk kerja sama yang sangat erat kaitan antara anggota kelompok. Hal tersebut membuktikan bahwa dengan diterapkankannya model NHT (Number Heads Together) dapat meningkatkan aktivitas siswa. Berdasarkan yang dikemukakan oleh Lie (Syarfuni, 2014:85) menyatakan bahwa NHT memberikan 
kesempatan kepada siswa untuk saling membagikan ide-ide dan mempertimbangkan jawaban yang paling tepat.

\section{Minat belajar siswa setelah menggunakan model NHT (Number Heads Together) pada mata pelajaran matematika.}

Minat belajar siswa merupakan suatu hal yang harus diutamakan terlebih dahulu dalam melakukan suatu pembelajaran didalam kelas. Karena jika dari awal minat pada suatu materi pelajaran sudah ada maka seseorang guru akan lebih mudah dalam menyampaikan pembelajaran. Hal ini sesuai dengan yang dikatakan Susanto (2014:58) minat merupakan " dorongan dalam diri seseorang atau faktor yang menimbulkan ketertarikan atau perhatian secara efektif, yang menyebabkan dipilihnya suatu objek atau kegiatan yang menguntungkan, menyenangkan, dan lama-kelamaan akan mendatangkan kepuasaan dalam dirinya. Hal ini sejalan dengan pendapat Getzel (Majid, 2014:49), minat adalah suatu disposisi yang terorganisir melalui pengalaman yang mendorong seseorang untuk memperoleh objek khusus, aktivitas, pemahaman, dan keterampilan untuk tujuan perhatian atau pencapaian.

Pengukuran minat belajar yang dimasukkan dalam penelitian ini, peneliti menggunakan lembar angket yang disebarkan oleh peneliti dan diisi oleh siswa kelas V yang berjumlah 28 orang. Pada siklus I setelah peneliti menerapkan model NHT (Number Heads Together) pada mata pelajaran matematika, peneliti memperoleh hasil 55,17\% dengan kategori kurang. Hal ini terjadi karena siswa belum terbiasa menggunakan model NHT (Number Heads Together) pada mata pelajaran matematika. Untuk itu, peneliti akan memperbaikinya pada siklus berikutnya yaitu siklus II. Pada siklus II peneliti memperoleh hasil dari lembar angket yang disebarkan pada siswa kelas V sebesar 77,38 dengan kategori sangat baik. Berdasarkan hasil yang diperoleh peneliti tersebut jelas bahwa minat siswa hanya 55,17 menigkat menjadi 77,38 pada siklus II, dari kategori kurang menjadi sangat baik dan dengan peningkatan sebesar 21,83.

Berdasarkan hasil tersebut maka jelas bahwa model NHT (Number Heads Together) dapat meningkatkan minat belajar siswa, karena siswa tidak hanya belajar dengan serius tetapi siswa juga dapat belajar sambil bermain. Dengan demikian, penelitian pada siklus II berhasil dengan menggunakan model NHT (Number Heads Together) dapat meningkatkan minat belajar siswa pada mata pelajaran matematika. Sebagaimana penelitian ini diperkuat oleh penelitian terdahulu oleh purwadi (2015) dengan judul upaya meningkatkan minat dan hasil belajar siswa melalui model pembelajaraan kooperatif tipeNumbered head together (NHT)pada siswa kelasVIIIE SMP $\mathrm{N} 2$ Sedayu Tahun Ajaran 2014/2015, dari penelitian terdahulu terbukti dengan menggunakan model NHT (Number Heads Together) dapat meningkatkan minat belajar siswa.Hal ini dibuktikan berdasarkan penelitian terdahulu yaitu oleh Ghani Abdul (2015) dengan judul "Pengaruh Model 
Pembelajaran Dan Persepsi Tentang Matematika Terhadap Minat Dan Hasil Belajar Matematika Siswa SMP Negeri di Kecamatan Salomekko Kabupaten Bone".

\section{Hasil belajar siswa setelah menggunakan model NHT (Number Heads Together)}

Hasil belajar merupakan kemampuan yang diperoleh anak setelah anak melakukan proses pembelajaran. Sebagaimana yang dikatakan oleh Purwanto (2016:44) hasil belajar sering kali digunakan sebagai ukuran untuk mengetahui seberapa jauh seseorang menguasai bahan yang sudah diajarkan.Pengukuran hasil belajar dalam penelitian ini menggunakan soal tes yang disebarkan kepada siswa kelas V. Soal tes diberikan pada siswa sebanyak 2 kali yaitu pada akhir siklus I dan siklus II. Penggunaan soal tes bertujuan untuk mengetahui tingkat ketercapaian siswa dalam memahami suatu materi pelajaran yang disampaikan oleh guru.

Berdasarkan data yang diperoleh peneliti, hasil belajar siswa pada siklus I ketuntasan secara klasikal yang diperoleh adalah sebesar $32,14 \%$ dengan rata-rata 39,46 dan dengan kategori kurang. Hal ini terjadi karena siswa masih belum memahami materi yang disampaikan oleh guru dan siswa juga belum bisa belajar menggunakan model NHT (Number Heads Together) pada mata pelajaran matematika khususnya pada materi geometri yaitu bangun ruang kubus dan balok. Hal ini sesuai dengan yang dikatakan oleh Sutikno (2009 : 14) menjelaskan bahwa ada beberapa faktor yang mempengaruhi hasil belajar siswa baik dari dalam individu (internal)maupun dari luar individu (eksternal) atau bisa gabungan dari kedua faktor tersebut. Untuk itu, peneliti ingin memperbaikinya pada siklus II selanjutnya.

Pada siklus II peneliti berhasil memperoleh ketuntasan klasikal siswa sebesar $92,85 \%$ dengan rata-rata nilai 80,89 dan dengan kategori sangat baik. Pada siklus II ini siswa juga sudah jauh lebih memahami materi yang disampaikan dan siswa juga sudah terbiasa dalam menggunakan model NHT (Number Heads Together) pada mata pelajaran matematika. Berdasarkan hasil yang diperoleh peneliti dari siklus I sampai dengan siklus II menunjukkan bahwa terdapat peningkatan pada setiap siklusnya. Hal ini dibuktikan oleh penelitian terdahulu oleh Syarfuni (2015) dengan judul penerapan model pembelajaran kooperatif tipe NHT untuk meningkatkan hasil belajar matematika keliling dan luas jajar genjang siswa kelas $\mathrm{V}$ SDN 32 Banda Aceh.

Hal tersebut dapat dibuktikan dengan berdasarkan data yang diperoleh hasil sebesar $32,14 \%$ dengan kategori kurang, meningkat pada siklus II sebesar $92,85 \%$ dengan kategori sangat baik. Dengan demikian, jelas bahwa penelitian pada siklus II yang dilakukan oleh peneliti berhasil dan tentunya dengan menerapkan model NHT (Number Heads Together) siswa tidak hanya belajar namun siswa juga dapat sambil bermain.

Untuk itu secara tidak langsung siswa tidak merasa bosan saat belajar dan tidak merasa terbebani dengan materi matematika 
yang lebih sering siswa menganggapnya susah untuk dipecahkan. Hal ini sesuai dengan yang diungkapkan oleh Megawati (2014:46) model (Number Heads Together) ini membuat siswa belajarsecara berkelompok sehingga siswa menjadi aktif dalam pembelajaran. Dengan demikian hasil belajar siswa berhasil ditingkatkan pada siklus II dengan menerapkan model (Number Heads Together). Hasil belajar meningkat dari setiap siklusnya, dapat disimpulkan bahwa hasil belajar meningkat dengan menggunakan model (Number Heads Together)

\section{SIMPULAN (PENUTUP)}

Simpulan dari hasil penelitian tindakkan kelas ini yaitu:

1. Penggunaan model (Number Heads Together) dapat berjalan dengan baik, berdasarkan hasil lembar observasi aktivitas belajar siswa pada siklus I diperoleh dengan rata-rata rata-rata $74,4 \%$ (kategori baik ) dan pada siklus II dengan rata-rata $94,44 \% \%$ (kategori sangat baik). Dari siklus 1 kesiklus II terjadi peningkatan sebesar $20,04 \%$.

2. Minat belajar siswa terhadap mata pelajaran matematika terus meningkat dari setiap siklusnya. Berdasarkan lembar angket siswa yang disebarkan diawal sebelum diterapkannya model (Number Heads Together) diperoleh hasil sebesar $34,71 \%$ dengan kategori kurang. Dan pada siklus II meningkat menjadi 77,38 (kategori sangat baik), dari siklus I kesiklus II terjadi peningkatan sebesar $22,17 \%$.
3. Hasil belajar siswa dari tes siklus I dengan rata-rata siswa sebesar 39,46 dengan ketuntasan klasikal 32,14\% (kategori kurang) meningkat pada siklus II dengan rata-rata nilai siswa 80,89 dengan ketuntasan klasikal 92,85\% (kategori sangat baik).

\section{DAFTAR PUSTAKA}

Apriadi, E.J. 2016. Penggunaan Metode Eksperimen dan Diskusi (Kelompok) Untuk Meningkatkan Prestasi Belajar Siswa Kelas IV Pada Mata Pelajaran IPA Tahun Pelajaran 2016/2017. Skripsi. Sintang: STKIP.

Arikunto.S.,Suhardjono.,Supardi. 2014. Penelitian Tindakan Kelas. Jakarta: PT Bumi Aksara.

Fathurrohman. M. 2015. Model-Model Pembelajaran Inovatif. Jogjakarta: ArRuzz Media

Hafid, A., Ahiri,J., Haq, D. 2013. Konsep Dasar Ilmu Kependidikan. Bandung: Alfabeta

Huda, M.2015. Model-Model Pengajaran dan Pembelajaran. Yogyakarta: Pustaka Belajar.

Jihad, A. 2013. Evaluasi Pembelajaran. Yogyakarta: Multi Pressindo.

Karwati, E., Priansa. D.J. 2014. Manajemen Kelas (Classroom Management) Guru Profesional Yang Inspiratif, Kreatif, Menyenangkan, Dan Berprestasi. Bandung: Alfabeta.

Ningrum, E. 2014. Penelitian Tindakan Kelas. Yogyakarta: Ombak.

Purwanto. 2016. Evaluasi Hasil Belajar. 
Yogyakarta: Pustaka Belajar.

Shoimin, A. 2014. 68 Model Pembelajaran Inovatif dalam Kurikulum 2013. Yogyakarta: Ar-Ruzz Media.

Slameto. 2013. Belajar Dan Faktor-Faktor yang Mempengaruhi. Jakarta: Rineka Cipta.

Sudjana, N. 2014. Penilaian Hasil Proses Belajar Mengajar. Bandung: Rozda.

Susanto, A. 2014. Teori Belajar Pembelajaran. Jakarta:

Kencana.Bandung: PT Remaja Rosdakarya.

Sugiyono. 2014. Metode Penelitia Kuantitatif,Kualitatif,dan $R \& D$. Bandung: Alfabeta.

Sugiyono. 2015. Metode Penelitia Kuantitatif,Kualitatif,dan $R \& D$. Bandung: Alfabeta.

Sundayana, R. 2015. Media dan Alat Peraga Dalam Pembelajaran Matematika. Bandung: Alfabeta 